\title{
Peningkatan Hasil Produksi melalui Pemanfaatan Alat Pendingin Kue Lapis Double Fan Pada Kelompok Usaha Makanan Ringan “ASIH” Dusun Kwasen Desa Srimartani Kecamatan Piyungan Kabupaten Bantul Yogyakarta
}

\author{
Laila Nafisah, dan Ahmad Muhsin \\ Program Studi Teknik Industri \\ Universitas Pembangunan Nasional "Veteran"Yogyakarta \\ Jl. Lingkar Utaran (SWK) 204 Condong Catur, Yogyakarta 55283 \\ Phone : +62 274485 733, Fax : +62 274486256 \\ e-mail : laila.nafisah@yahoo.co.id, ahmad.muhsin@upnyk.ac.id
}

\begin{abstract}
Kelompok usaha "ASIH” merupakan salah satu bentuk usaha warga yang terdiri dari 7 keluarga yang memproduksi berbagai macam makanan untuk keperluan hajatan dan lain sebaginya khususnya pembuatan kue lapis basah. Kelompok Usaha "ASIH” memproduksi kue lapis yang dipasarkan dengan 2 cara untuk memenuhi permintaaan konsumen yaitu melalui pasar tradisional setiap pagi dan menerima pesanan dari warga. Penerimaan pesanan yang banyak yang datang dari berbagai kalangan menjadi keuntungan namun juga menjadi kendala. Banyaknya pesanan tidak serta merta dapat diterima karena beberapa keterbatasan, diantaranya adalah keterbatan alat produksi.

Proses produksi dalam pembuatan kue lapis yang memerlukan waktu lama, sekitar 12 jam menjadi salah satu pertimbangan terhadap beberapa permintaan yang datang akan diterima atau tidak, disamping jumlah pesanan yang diminta. Lamanya waktu produksi membatasi kemampuan jumlah produksi dalam setiap harinya. Pesanan yang dijadwalkan akan diambil oleh pembeli pada esok pagi hari maka mulai pengerjaannya sudah dilakukan sejak sore hari sebelumnya. Waktu paling lama dalam proses pembuatan kue lapis sejak persiapan bahan baku sampai tahap pengemasan terletak pada proses pendinginan yang memakan waktu lama kurang lebih 7 jam. Proses pendinginan dilakukan secara manual dengan cara diangin-anginkan sampai suhu turun dan menjadi dingin, kue lapis akan mengeras sehingga dapat dipotong-potong kemudian dikemas sesuai ukuran permintaan konsumen.

Solusi pemecahan yang dapat diberikan untuk mempercepat pendinginan pada proses produksi kue lapis pada Kelompok Usaha “ ASIH” adalah dengan membuat sebuah alat atau mesin pendingin yang dirancang dengan merangkai mesin rotator yang mampu menggerakkan baling-baling untuk memutarkan pergerakan angin dalam sebuah desain konstruksi ruang yang dirancang spesifik untuk proses pendinginan kue lapis, menggunakan prinsip kerja kipas angin maka angin yang terbentuk diarahkan untuk mencapai Loyang - Loyang yang ditata khusus dalam sebuah wadah sehingga dalam satu proses pendinginan diharapkan dapat mendinginkan banyak Loyang.
\end{abstract}

Keywords : alat pendingin kue lapis, makanan ringan.

\section{PENDAHULUAN}

Kehidupan masyarakat di Desa Srimartani Piyungan Bantul Yogyakarta banyak ditopang dari mata pencaharian petani dan pedang. Perputaran ekonomi di wilayah ini termasuk maju karena didukung dengan tersedianya pasar tradisional yang aktif setiap hari yang berlokasi di Dusun Kwasen Srimartani sebagai pusat jual beli masyarakat. Masyarakat Desa Srimartani khususnya Dusun Kwasen memanfaatkan keberadaan pasar ini dengan memperjualbelikan berbagai produk baik hasil bumi, kelontong, maupun produk makanan tradisional yang mereka produksi sendiri.

$$
\text { Kelompok usaha "ASIH" }
$$
merupakan salah satu bentuk usaha warga yang terdiri dari 7 keluarga yang memproduksi berbagai macam makanan untuk keperluan hajatan dan lain sebaginya khususnya pembuatan kue lapis basah. Dari pembicaraan awal dengan pemilik diperoleh informasi bahwa Kelompok Usaha ini telah memilik langganan yang banyak terbukti dari banyaknya pesanan yang sering 
diterima dan telah menjangkau radius 3 $\mathrm{km}$. Keinginan untuk mengembangkan usaha dilakukan dengan mengikuti berbagai pelatihan usaha dan telah mengajukan untuk mendapatkan ijin PIRT.

Kue lapis merupakan makanan khas Indonesia yang dibuat dari dua warna yang ditumpuk berlapis-lapis, Biasanya Kue lapis dibuat dengan tepung beras, tepung terigu,atau tepung kanji. Rasanya kenyal, legit dan manis membuat kue ini tetap disukai oeh semua kalangan. Kue lapis yang baik biasanya berwarna merah atau hijau, karena dibuat dengan pewarna alami yaitu daun pandan atau sirup, sehingga kue lapis aman dikonsumsi untuk anak anak maupun dewasa. Untuk membuat kue lapis tidak terlalu susah hanya saja memang setiap bahan harus dikukus satu satu, bahan bakunya juga mudah didapat.

Kelompok Usaha "ASIH" memproduksi kue lapis yang dipasarkan dengan 2 cara untuk memenuhi permintaaan konsumen yaitu melalui pasar tradisional setiap pagi dan menerima pesanan dari warga. Kue lapis yang dihasilkan juga sering dipesan untuk keperluan hidangan dalam berbagi keperluan hajat warga seperti pernikahan, pertemuan warga, pengajian, maupun pesta lain. Penerimaan pesanan yang banyak yang datang dari berbagai kalangan menjadi keuntungan namun juga menjadi kendala. Banyaknya pesanan tidak serta merta dapat diterima karena beberapa keterbatasan, diantaranya adalah keterbatan alat produksi.

Proses produksi dalam pembuatan kue lapis yang memerlukan waktu lama, sekitar 12 jam menjadi salah satu pertimbangan terhadap beberapa permintaan yang datang akan diterima atau tidak, disamping jumlah pesanan yang diminta. Lamanya waktu produksi membatasi kemampuan jumlah produksi dalam setiap harinya. Pesanan yang dijadwalkan akan diambil oleh pembeli pada esok pagi hari maka mulai pengerjaannya sudah dilakukan sejak sore hari sebelumnya. Waktu paling lama dalam proses pembuatan kue lapis sejak persiapan bahan baku sampai tahap pengemasan terletak pada proses pendinginan yang memakan waktu lama kurang lebih 7 jam. Proses pendinginan dilakukan secara manual dengan cara diangin-anginkan sampai suhu turun dan menjadi dingin, kue lapis akan mengeras sehingga dapat dipotong-potong kemudian dikemas sesuai ukuran permintaan konsumen.

Keterbatasan ruang dan peralatan dalam proses pendinginan menjadikan tahapan pembuatan kue lapis hanya mampu dilakukan dalam satu kali periode pembuatan. Pesanan berikutnya baru dikerjakan setelah pembuatan pertama selesai. Dalam satu hari rata-rata kemampuan produksi Kelompok Usaha "ASIH" hanya mampu membuat satu kali pesanan per hari dengan kapasitas maksimal 10 loyang (tempat cetakan kue lapis).

\section{METODE PENELITIAN}

Solusi pemecahan yang dapat diberikan untuk mempercepat pendinginan pada proses produksi kue lapis pada Kelompok Usaha " ASIH" adalah dengan membuat sebuah alat atau mesin pendingin yang dirancang dengan merangkai mesin rotator yang mampu menggerakkan baling-baling untuk memutarkan pergerakan angin dalam sebuah desain konstruksi ruang yang dirancang spesifik untuk proses pendinginan kue lapis, menggunakan prinsip kerja kipas angin maka angin yang terbentuk diarahkan untuk mencapai Loyang - Loyang yang ditata khusus dalam sebuah wadah sehingga dalam satu proses pendinginan diharapkan dapat mendinginkan banyak Loyang serta mampu diatur sesuai kebutuhan.

Berikut adalah desain gambar alat pendingin kue lapis double fan: 


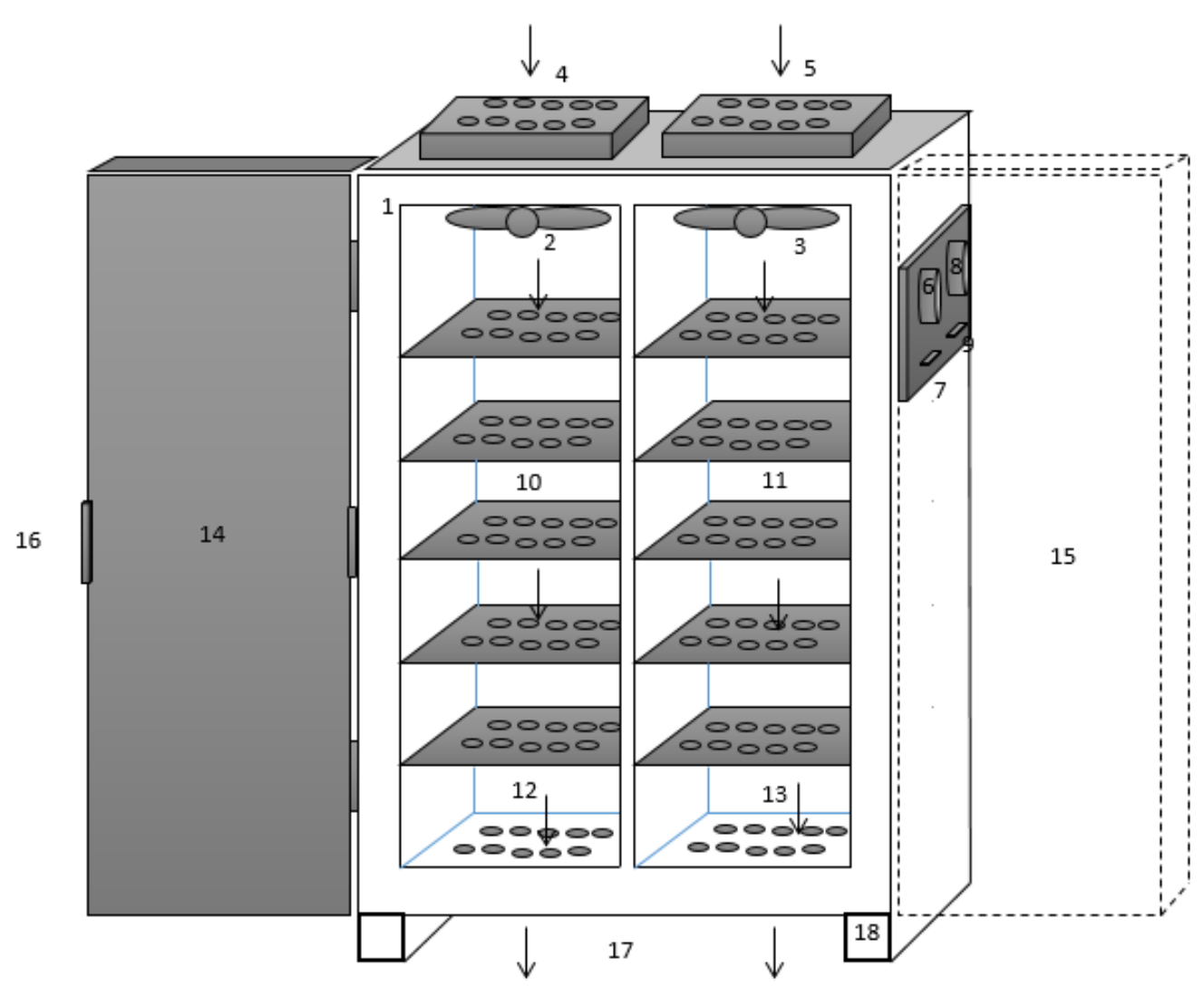

Gambar 1. Double box fan

Keterangan gambar :

1. Box rangka

2. Kipas Kiri

3. Kipas Kanan

4. Jalan masuk angin kiri (dgn filter)

5. Jalan masuk angin kanan (dgn filter)

6. Pengatur kecepatan kipas Kiri

7. Tombol on/off kipas kiri

8. Pengatur kecepatan kipas kanan

9. Tombol on/ off kipas kanan

10. Rak Loyang kiri

11. Rak Loyang kanan

12. Jalan angin keluar Kiri

13. Jalan angin keluar kanan

14. Pintu Kiri

15. Pintu Kanan

16. Kunci pintu

17. Ruang ventilasi keluar

18. Dudukan penyangga
Alat pendingin kue lapis ini terdiri dari dua pintu dengan dua kipas dengan setiap pintu memiliki 5 susunan rak yang berfungsi untuk membagi kerja agar dapat diseuaikan dengan jumlah pesanan yang diterima, serta proses produksi mampu berjalan dalam dua pekerjaan sehingga dapat mempercepat proses pendinginan baik melalui sisi pekerjaan yang dilakukan maupun dari sisi kecepatan perputaran angin yang dihasilkan dari 2 mesin motor penggerak yang dapat diputar sesuai kebutuhan. Perpindahan angin yang masuk dari luar alat akan disaring melalui filter untuk mencegah kotoran, baling-baling akan menghembuskan angin melewati rak-rak berlubang sehingga proses pendinginan dapat merata kesemua rak dalam alat pendingin. Diharapkan dengan alat pendingin ini proses pendinginan kue lapis dapat dipercepat menjadi 3 jam atau bahkan lebih cepat lagi. 


\section{PEMBAHASAN}

Teknologi yang diberikan pada kegiatan pengabdian masyarakat yang di Kelompok Usaha “ ASIH” Dusun Kwasen adalah perancangan alat pendingin kue lapis dengan menggunakan Double Fan. Alat pendingin kue lapis ini terdiri dari dua pintu dengan dua kipas dengan setiap pintu memiliki susunan rak yang berfungsi untuk membagi kerja agar dapat diseuaikan dengan jumlah pesanan yang diterima, serta proses produksi mampu berjalan dalam dua pekerjaan sehingga dapat mempercepat proses yang dihasilkan dari 2 mesin motor penggerak yang dapat diputar sesuai kebutuhan.

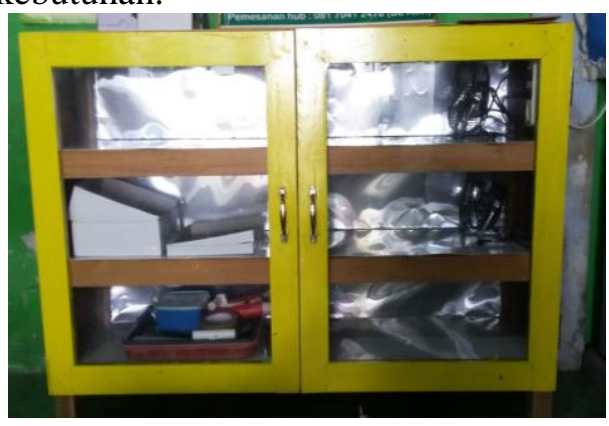

Gambar 2 Hasil rancangan alat pendingin kue lapis

Perpindahan angin yang masuk dari luar alat akan disaring melalui filter untuk mencegah kotoran, baling-baling akan menghembuskan angin melewati rak-rak berlubang sehingga proses pendinginan dapat merata kesemua rak dalam alat pendingin. Setelah dilakukan uji coba dengan alat pendingin ini proses pendinginan kue lapis dapat dipercepat menjadi 3 jam artinya alat ini berhasil memberikan kontribusi mempercepat proses pendinginan sebesar $50 \%$. Berikut adalah hasil kue lapis yang dihasilkan :

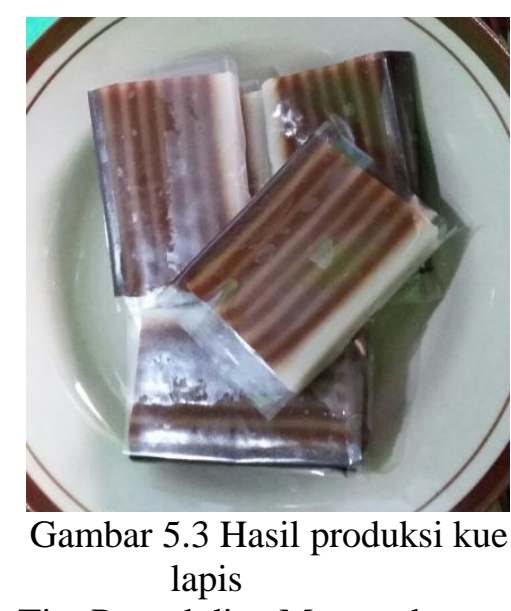

Tim Pengabdian Masyarakat UPN Veteran Yogyakarta menyerahkan alat pendingin kue lapis :

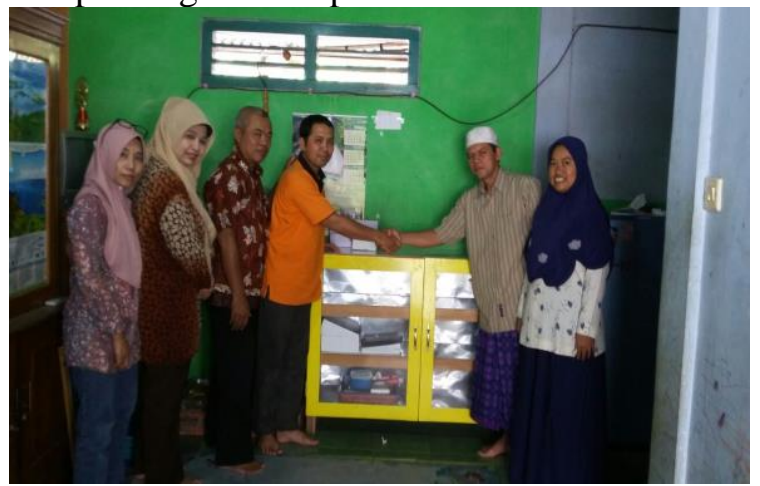

Gambar 3 Penyerahan alat pendingin kue lapis

Hasil produksi yang dibuat biasa dipesan masyarakat untuk keperluan berbagai hajatan seperti pamit haji, pengajian, dan lain sebagainya. Untuk keperluan penguatan kemampuan produksi maka dalam kegiatan pengabdian ini juga diberikan kelengkapan penguatan produksi meliputi perlengkapan masak.

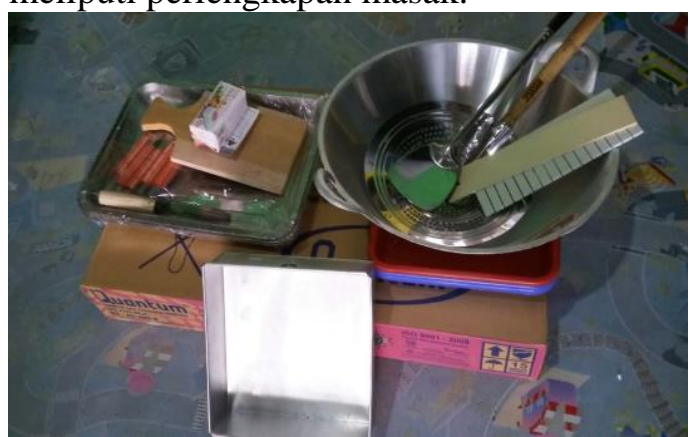

Gambar 5 Dukungan alat penguatan produksi 
Untuk mendukung identitas usaha dan pengenalan produk hasil usaha kepada masyarakata maka tim pengabdian UPN Veteran Yogyakarta juga dibuatkan merk dagang yang diberi nama HANA SNACK

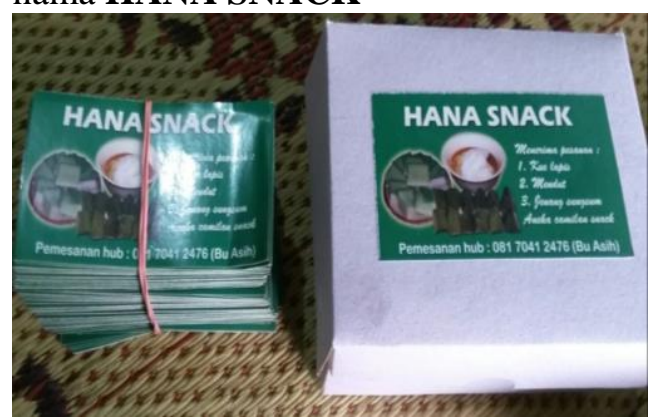

Gambar 6 Pembuatan Merk Dagang "HANA SNACK"

Tim juga membuatkan papan pengenal dan penunjuk arah kepada kelompok usaha yang berfungsi selain sebagai alat promosi juga memberikan kemudahan kepada masyarakat untuk menemukan lokasi usaha dan melakukan pemesanan.

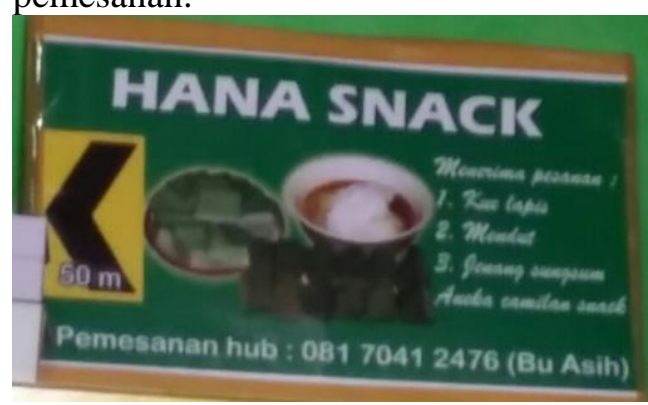

Gambar 7 Papan penunjuk arah

\section{KESIMPULAN}

Peran dan kerjasama pemilik Kelompok Usaha " ASIH" dalam proses pembuatan alat pendingin ini dengan bersama-sama perancang menentukan kebutuhan peralatan dan kondisi yang paling sesuai untuk menghasilkan kue lapis yang bermutu, menyediakan ruang dan peralatan produksi yang ada sebagai media simulasi proses produksi dan instalasi, turut serta memantau dan memberikan usulan arahan desain rancang bangun alat, serta menjalankan alat pendingan yang telah selesai dirancang. Serta sinergi antara pemilik Kelompok Usaha “ ASIH” dan perancang (dalam hal ini kami selaku dosen Teknik Industri) telah mampu menghasilkan alat pendingin yang mampu memberikan kontribusi dalam mempercepat proses produksi yang tadinya membutuhkan waktu 7 jam pendinginan dapat dipersingkat menjadi 3 jam.

\section{DAFTAR PUSTAKA}

Efendi, T. N. (1993) Sumber Daya Manusia, Peluang Kerja dan Kemiskinan, PT. Tiara Wacana, Yogyakarta

Mikkelsen, B. (2003) Metode Penelitian Partisipatoris dan UpayaUpaya Pemberdayaan, Terjemahan: Mathoes Nalle, Yayasan Obor, Jakarta

Remi, S. S. Dan P. Tjiptoherijanto (2002) Kemiskinan dan Ketidakmerataan di Indonesia, Rineka Cipta, Jakarta.

Rusli, S. (1995) Metodologi Identifikasi Golongan dan Daerah Miskin: Suatu Tinjauan dan Alternatif, PT. Gramedia Widiasarana Utama dan Institut Pertanian Bogor, Bogor

Soegijoko, B. T. S. Dan B. S. Kusbiantoro (1997) Bunga Rampai Perencanaan Pembangunan di Indonesia, Yayasan Soegijanto Soegijoko, Bandung 